\title{
Carbon and nitrogen accumulation within four black walnut alley cropping sites across Missouri and Arkansas, USA
}

\author{
Andrew L. Thomas (D) Robert Kallenbach • Thomas J. Sauer • David K. Brauer • \\ David M. Burner • Mark V. Coggeshall • Christian Dold • Wendi Rogers • \\ Sougata Bardhan $\cdot$ Shibu Jose
}

Received: 7 January 2019/Accepted: 16 December 2019/Published online: 24 January 2020

(C) The Author(s) 2020

\begin{abstract}
Agroforestry systems that integrate useful long-lived trees have been recognized for their potential in mitigating the accumulation of atmospheric fossil fuel-derived carbon (C). Black walnut (Juglans nigra) is frequently planted and cultivated in North America for its valuable lumber and edible nuts, and is highly amenable to the integration of understory crops or livestock in agroforestry systems. However, little is known about $\mathrm{C}$ content in black walnut trees, including the amounts of $\mathrm{C}$ assimilated into lignocellulosic tissues within different tree compartments. Therefore, allometric equations for above- and below-ground compartments of 10-year-old black walnut trees across diverse locations were developed. Ten grafted black walnut trees from each of four sites across the midwestern USA were destructively harvested for
\end{abstract}

\section{A. L. Thomas ( $\square)$}

Division of Plant Sciences, Southwest Research Center, University of Missouri, Mt. Vernon, MO 65712, USA

e-mail: thomasal@missouri.edu

R. Kallenbach

Division of Plant Sciences, University of Missouri,

Columbia, MO 65211, USA

T. J. Sauer · C. Dold

National Laboratory for Agriculture and the Environment, USDA-ARS, Ames, IA 50011, USA

D. K. Brauer

Conservation and Production Research Laboratory,

USDA-ARS, Bushland, TX 79012, USA above- and below-ground biomass, and dry biomass weight $\left(\mathrm{DW}_{\mathrm{w}}\right), \mathrm{C}\left(\mathrm{C}_{\mathrm{w}}\right)$ and nitrogen $\left(\mathrm{N} ; \mathrm{N}_{\mathrm{w}}\right)$ stocks were quantified. Soils surrounding the harvested trees were sampled and analyzed for soil organic C (SOC) and total $\mathrm{N}(\mathrm{TN})$. Total $\mathrm{DW}_{\mathrm{w}}$ ranged from 27 to $54 \mathrm{~kg}$ tree ${ }^{-1}$, with woody tissues containing an average of $467 \mathrm{~g} \mathrm{~kg}^{-1} \mathrm{C}$ and $3.5 \mathrm{~g} \mathrm{~kg}^{-1} \mathrm{~N}$. Woody tissues differed in $\mathrm{C}_{\mathrm{w}}$ and $\mathrm{N}_{\mathrm{w}}$ across location, and aboveground sections contained more $\mathrm{C}$ and less $\mathrm{N}$ compared with most root tissues. The slopes of the allometric equations did not differ significantly among locations, while intercepts did, indicating that trees only differed in initial size across locations. SOC and TN did not vary in distance from the trees, likely because the trees were not yet old enough to have impacted the surrounding soils. Our results establish a

\section{M. Burner}

Dale Bumpers Small Farms Research Center, USDA-

ARS, Booneville, AR 72927, USA

M. V. Coggeshall · W. Rogers · S. Bardhan

Center for Agroforestry, University of Missouri,

Columbia, MO 65211, USA

M. V. Coggeshall

Northern Research Station, USDA Forest Service,

West Lafayette, IN 47907, USA

S. Jose

College of Agriculture, Food, and Natural Resources, University of Missouri, Columbia, MO 65211, USA 
foundation for quantifying $\mathrm{C}$ and $\mathrm{N}$ stocks in newly established black walnut alley cropping systems across diverse environments.

Keywords Juglans nigra $\cdot$ Allometry $\cdot$ Root-shoot ratio $\cdot \log -\log$ models

\section{Introduction}

While numerous studies have estimated the carbon (C) accumulation potential for forests (e.g., Harmon 2001; Nepal et al. 2012; Woodbury et al. 2007), Nair et al. (2009) specifically proposed agroforestry as a strategy for impactful $\mathrm{C}$ assimilation; this is further supported by data from Cardinael et al. (2018a, b). Agroforestry systems that integrate woody species with other crops or livestock can provide a high marginal rate of return for producers (Benjamin et al. 2000), including the potential sale of $\mathrm{C}$ credits as such markets emerge (Udawatta and Jose 2012). Alleycropping and silvopasture practices that incorporate long-lived woody plants into productive agricultural systems can sequester fossil fuel-derived $\mathrm{C}$ into stable and benign ligneous forms for decades (Verchot et al. 2007); mean $C$ residence time depends on tree species and longevity, decomposition rate, and ultimate use of lumber and other wood products (Profft et al. 2009). Carbon assimilation that occurs in agroforestry farming systems is being recognized as a viable strategy for sequestration under the Clean Development Mechanism of the Kyoto Protocol to the United Nations Framework Convention on Climate Change (UNFCCC 2006), as well as by the Intergovernmental Panel on Climate Change (Cardinael et al. 2018a). For example, Udawatta and Jose (2012) estimated that agroforestry could offset current US $\mathrm{CO}_{2}$ emission by $33 \%$, with alley cropping accounting for $10 \%$ of the potential $\mathrm{C}$ sequestered by agroforestry practices. However, detailed studies are necessary to accurately quantify the amounts and rates of $\mathrm{C}$ assimilation in lignocellulosic biomass and in soils associated with various agroforestry species and practices to encourage adoption of such systems (Dollinger and Jose 2018; Udawatta and Jose 2012). Nitrous oxide, often released from agricultural systems as a result of excessive $\mathrm{N}$ fertilization or underutilization of $\mathrm{N}$ fertilizers by crops, has also been implicated in climate change (Ravishankara et al. 2009); therefore $\mathrm{N}$ assimilation into lignocellulosic tissues within agroforestry systems also merits study.

Black walnut (Juglans nigra L.) is indigenous to eastern North America and is well known for its highvalue timber and edible nut production (Câmara and Schlegel 2016; Chenoweth 1995; Wolz and DeLucia 2019). The species is often cultivated and managed for lumber and veneer production, while intensive orchards of trees grafted to improved cultivars specifically for nut production are emerging (Reid et al. 2009). Black walnut trees are relatively fast growing under ideal conditions of soil type, soil fertility, and moisture, and are of interest in terms of $\mathrm{C}$ assimilation because they are frequently cultivated and because of their longevity. Most black walnut nut production orchards are established as widely spaced alley cropping systems, wherein other agricultural crops can be produced for several years until canopy closure (Garrett and Harper 1998). Black walnut alley cropping-based nut production systems can provide multiple income streams to producers while providing significant ecosystem services, including long-term $\mathrm{C}$ and $\mathrm{N}$ assimilation. However, little is known about $\mathrm{C}$ and $\mathrm{N}$ distribution and cycling in black walnut trees and surrounding soils, especially those grown in alley cropping practices. A better understanding of $\mathrm{C}$ stocks within black walnut production systems may also increase opportunities for the sale of $\mathrm{C}$ credits as that market expands. Data on the assimilation and distribution of $\mathrm{N}$ in such trees will contribute to more efficient $\mathrm{N}$ fertilizer use, less $\mathrm{N}$ runoff, and less evolution of nitrous oxide from agroforestry systems (e.g., Wolz et al. 2018).

Allometric equations are commonly used in estimating biomass production, and $\mathrm{C}$ and $\mathrm{N}$ accumulation by trees (e.g., Chojnacky et al. 2014; Dold et al. 2019; Jacobs et al. 2009; Jenkins et al. 2004; McPherson et al. 2016). However, the allometry of trees managed in agroforestry systems and within different environments is still poorly understood. Most allometric equations are derived from forest-grown trees that differ in their growth rate and canopy architecture compared with trees in alley cropping growth conditions, which can lead to substantial biomass over- and under-estimations (Zhou et al. 2014). Trees in agroforestry systems are less exposed to mutual shading compared with forest trees, and have a higher branch biomass and different tree 
architecture with greater specific gravity (dependent on species) to support the larger tree canopy (Zhou et al. 2011; Schroth et al. 2015). In addition, trees have a high physiological and morphological plasticity to adapt to resource limitations, such as water, nutrients, and solar radiation, all of which change with sitespecific climatic and soil conditions (Grams and Andersen 2007; Stovall et al. 2013), and which impact allometric equations (Lines et al. 2012). To the best of our knowledge these site-specific differences have not been addressed for black walnut allometry in alley cropping systems specifically to address $\mathrm{C}$ and $\mathrm{N}$ accumulation. Furthermore, previous studies of black walnut did not comprehensively estimate above- and below-ground $\mathrm{C}$ and $\mathrm{N}$ accumulation. Several studies investigated black walnut roots in agroforestry systems without considering below-ground $\mathrm{C}$ (Awaz et al. 2018; Germon et al. 2016; Zhang et al. 2015), or used general allometric equations from literature (Cardinael et al. 2017). Other studies focused only on black walnut above-ground compartments (Dupraz et al. 1999; Zellers et al. 2012). Ares and Brauer (2004) and Brauer et al. (2006) estimated nut production of black walnut varieties with allometric equations across different sites in the Midwestern US.

Site- and management-specific allometric equations for different tree species under various agroforestry practices need to be developed to enable better understanding of biomass production, $\mathrm{C}$ accumulation, and nutrient uptake in agroforestry systems. The objectives of this study were to quantify soil and tree biomass $\mathrm{C}$ and $\mathrm{N}$ in black walnut alley cropping systems across four latitudinally distinct environments of similarly aged trees, and to establish site-specific allometric equations.

\section{Materials and methods}

Study locations and establishment

Ten grafted black walnut trees of similar age and origin from each of four different alley-cropping practices were destructively harvested, and the soil surrounding these trees extensively cored and sampled for this study. The four study sites are located in Missouri and Arkansas, USA (Table 1). Significant details on site location, design and establishment, alley vegetation establishment and management, soil chemistry, and weed and pest management were previously described (Brauer and Jones 2003; Burner et al. 2015; Coggeshall et al. 2003; Sauer et al. 2015; Thomas et al. 2008), with some relevant details summarized in Table 1. Specific details on site and tree fertilization at all four sites are provided in Thomas et al. (2008). The sites, arrayed north to south, were as follows:

New Franklin, MO (NF): The site was at the University of Missouri's Horticulture and Agroforestry Research Center near New Franklin in central Missouri. The soil was a Marshall silt loam (fine-silty, mixed, mesic Typic Hapludolls), a deep, well-drained, gently sloping, upland soil with moderate permeability and high water-holding capacity that formed on deep loess deposits (Grogger and Landtiser 1978). Site preparation began in summer 2000, then in February 2001, 180 trees were transplanted into nine rows

Table 1 Site descriptions (north to south) for the four black walnut alley cropping practices studied: New Franklin, MO (NF), Mount Vernon, MO (MV), Fayetteville, AR (FV), and Boonville, AR (BN)

\begin{tabular}{|c|c|c|c|c|}
\hline Factor & $\mathrm{NF}$ & MV & $\mathrm{FV}$ & $\mathrm{BN}$ \\
\hline Latitude $\mathrm{N}\left({ }^{\circ}\right)$ & 39.02 & 37.08 & 36.09 & 35.09 \\
\hline Longitude W $\left(^{\circ}\right)$ & 92.76 & 93.87 & 94.19 & 93.97 \\
\hline Elevation (m) & 197 & 378 & 427 & 139 \\
\hline USDA hardiness zone & $6 a$ & $6 a$ & $6 b$ & $7 b$ \\
\hline Annual rainfall (mm) & 975 & 1106 & 1094 & 1140 \\
\hline Tree spacing $(\mathrm{m})$ & $9.1 \times 9.1$ & $12.2 \times 9.1$ & $15 \times 9.1$ & $12.2 \times 7.6$ \\
\hline Soil type & Typic Hapludolls & Fluventic Hapludolls & Typic Fragiudults & Typic Hapludults \\
\hline Site index for black walnut $\mathrm{t}^{\mathrm{a}}$ & 65 & 80 & $60-65$ & $55-60$ \\
\hline
\end{tabular}

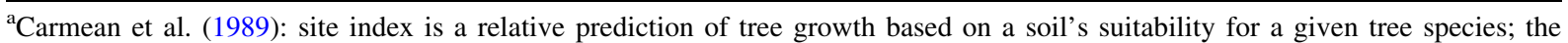
figures here are predicted black walnut tree height (in feet units) at 50 years. Data, respectively, from Grogger and Landtiser (1978), Hughes (1982), Harper et al. (1969) and Garner et al. (1980) 
covering 1.5 ha. Weeds and vegetation within a $1 \mathrm{~m}$ radius of each tree were suppressed with two annual applications of glyphosate herbicide; alley vegetation consisted of mixed grasses and weeds that were mowed periodically (Coggeshall et al. 2003; Thomas et al. 2008).

Mt. Vernon, MO (MV): The site was located at the University of Missouri's Southwest Research Center near Mt. Vernon in southwest Missouri. The soil was an alluvial Huntington silt loam (fine-silty, mixed, mesic Fluventic Hapludolls), a deep, level, welldrained soil that infrequently floods (Hughes 1982). The site was prepared by killing existing vegetation with glyphosate herbicide in fall 2000, and trees were transplanted in February 2001. The orchard had 120 trees in nine rows covering 1.4 ha. Weeds and vegetation within a $1 \mathrm{~m}$ radius of each tree were suppressed with two applications of glyphosate herbicide annually; vegetation beyond this area consisted of mixed grasses dominated by tall fescue (Festuca arundinacea Schreb.) that was mowed periodically (Coggeshall et al. 2003; Thomas et al. 2008).

Fayetteville, AR (FV): The site was at the Arkansas Agricultural Research and Extension Center at Fayetteville in northwest Arkansas. The slope at the site was south-facing, ranging from 1 to $8 \%$. Soils at the site formed from loamy deposits and cherty limestone residuum. Most of the site was Captina silt loam (finesilty, mixed, mesic Typic Fragiudults), which has a fragipan at $40-60 \mathrm{~cm}$ depth (Harper et al. 1969). Glyphosate herbicide was applied in April and July 1999 to kill existing vegetation. In November 1999, 91 black walnut trees were transplanted into five rows covering 1.25 ha. Weeds and vegetation near trees were suppressed with a weed barrier fabric $\left(1 \mathrm{~m}^{2}\right)$ for the first 5 years, and thereafter with periodic applications of glyphosate herbicide within a 1-m radius. Alleys were initially planted to orchardgrass (Dactylis glomerata L.) that was harvested as hay through 2005, after which mixed grasses and weeds were mowed periodically (Sauer et al. 2015).

Booneville, AR (BN): The site was located at the USDA-ARS Dale Bumpers Small Farms Research Center, near Booneville, in west-central Arkansas. The soil at the higher elevation was an Enders silt loam (clayey, mixed, thermic Typic Hapludults) that transitions into a Leadvale silt loam (fine-silty, siliceous, thermic Typic Fragiudults) down a 5\% slope. Both soils have low natural fertility, and are deep, moderately well drained, with slow water permeability and medium water-holding capacity (Garner et al. 1980). The site was chisel-plowed in November 1999 , after which trees were transplanted in December 1999. The orchard contained 72 trees in nine rows, and covered 0.7 ha. Approximately $40 \%$ of the trees suffered extensive damage due to a very heavy nut load in summer of 2002 and were replaced in January 2003 with similarly grafted trees. For this study, three trees from the 1999 planting, and seven from the 2003 planting were tested. Weeds and vegetation near trees were suppressed with a $1 \mathrm{~m}^{2}$ weed barrier fabric. Alley vegetation consisted of mixed tall fescue and bermudagrass [Cynodon dactylon (L.) Pers.] that was mowed periodically (Brauer and Jones 2003; Burner et al. 2015).

Soil core sampling and analysis

Prior to tree excavation, soil cores were collected around each of the 40 study trees using a hydraulic soil probe (a utility vehicle-mounted \#5-UV Model GSRPSUV at NF and MV; and a truck-mounted \#15-SCS Model GSRPS at FV and BN; Giddings Machine Co., Fort Collins, CO). Soil cores (4.4 cm at $\mathrm{NF}$ and $\mathrm{MV} ; 5.7 \mathrm{~cm}$ at $\mathrm{FV}$ and $\mathrm{BN}$ ) were taken at opposing 1,2, and $3 \mathrm{~m}$ radius positions measured from the center point of each tree trunk. Cores were taken in the direction of and within the tree rows at FV (eastwest), NF, and MV (both north-south), whereas at BN, cores were taken in all four cardinal directions. Thus, six cores per tree were collected at NF, MV, and FV, and 12 cores at BN. Cores were collected to a depth of $100 \mathrm{~cm}$ at the four sites if possible. In some cases (especially at FV), impediments (rocks and fragipan) in the soil profile prevented collection of the deeper samples. Soil cores from each position were separated into vertical sections of $0-10,10-20,20-50$, and $50-100 \mathrm{~cm}$ from the soil surface. A total of 891 soil samples were collected for analysis. Samples were initially stored at $<0{ }^{\circ} \mathrm{C}$, then later dried in a ventilated greenhouse (warm ambient temperature). Dried samples were ground with a hammer mill (Model C-H, Viking Manufacturing Co., Manhattan, $\mathrm{KS})$ to $<3 \mathrm{~mm}$, then $\mathrm{a} \approx 15 \mathrm{~g}$ subsample was further ground on a roller mill (Bailey Manufacturing Inc., Norwalk, IA) for $12 \mathrm{~h}$ to create a fine powder. A subsample of the powder was analyzed for soil organic carbon (SOC) and total nitrogen (TN) concentration 
via the dry combustion method using a Flash 1112 or 2000 elemental analyzer (Thermo Finnigan, San Jose, CA).

Tree resource, harvest, and biomass data collection

The black walnut trees harvested from the four sites were all 2 years old from seed when transplanted, plus 8-11 years post-transplanting age (Table 2). All were grafted to superior nut-producing cultivars and established for agroforestry and nut production studies. Trees at NF and MV were produced identically and simultaneously in our own nursery for an initial multilocation rootstock study (Coggeshall et al. 2003; Thomas et al. 2008). They were all 'Kwik-Krop' scions grafted to potted 1-year-old rootstocks (either 'Kwik-Krop', 'Sparrow', or 'Thomas' seedlings) in early Spring 2000, then maintained in the nursery that summer. Trees for FV were identical except that they were produced and transplanted 1 year earlier (Sauer et al. 2015). Trees from BN included 'Emma K', 'Kwik-Krop', 'Sauber', and 'Thomas' scions grafted to 'Kwik-Krop' and 'Thomas' seedling rootstocks in various combinations (Brauer and Jones 2003; Burner et al. 2015). Trees at $\mathrm{BN}$ were produced in a similar manner as the other trees, but by Forrest Keeling Nursery (Elsberry, MO).

Forty black walnut trees (ten per site) were selected for analysis, and harvested in 2011 as follows: NFweek of April 4, MV—week of March 21, FV—week of June 21, BN-week of March 28. Above-ground tree biomass was measured through modified methods described by Jacobs et al. (2009). Tree trunk diameter was measured at $137 \mathrm{~cm}$ above soil level (diameter at breast height; DBH). Trees were then felled and height measured. Above-ground tissues were separated into trunk, large branches ( $\geq 12 \mathrm{~cm}$ diameter), and small branches ( $<12 \mathrm{~cm}$ diameter), and fresh weight (FW) of all harvested materials determined. At time of harvest, leaves had emerged only at FV, but were not sampled. Cross-section samples of the trunks (approx. $5 \mathrm{~cm}$ thick) were collected at 30,60, 120, and $180 \mathrm{~cm}$ above soil level, and representative samples of large and small branches were selected. Fresh weight was determined for all samples, which were then dried in a propane-fired dryer $\left(\approx 50{ }^{\circ} \mathrm{C}\right)$ for several days until the weights stabilized, and then dry weight (DW) was measured. The fresh and dry weights of the samples were then correlated to total tree biomass on a percent basis.

Below-ground tree biomass was determined at MV and $\mathrm{BN}$ by digging around the root system to a radius of $1.5 \mathrm{~m}$ and about $1.4 \mathrm{~m}$ deep with a backhoe, then lifting the main root system from the ground using a backhoe and chains, making every attempt to maintain the integrity of the root system. While this sampling protocol was not able to obtain $100 \%$ of the roots, this was a uniform method that secured the largest roots in order to accomplish the project objectives. Soil was removed from the roots with a pressure washer. Root systems were then separated into large roots $(\geq 1.6 \mathrm{~cm}$ diameter), small roots $(<1.6 \mathrm{~cm}$ diameter), and root bole (the major solid, central, woody below-ground structure). Very fine feeder roots were not analyzed. A cross-section sample of the root bole (approx. $5 \mathrm{~cm}$ thick) was collected for each tree, as were sub-samples of large and small roots. Fresh and dry weights for samples and total below-ground biomass were determined as above.

Woody tissue $\mathrm{C}$ and $\mathrm{N}$ analysis

Woody tissue samples from small branches and roots were cut into small $(<1 \mathrm{~cm})$ pieces with a pruning shear. For larger-diameter tissues, a hand-held electric drill with $8 \mathrm{~mm}$-diameter drill bit was used to extract wood shavings in a representative manner from the sample. All samples were ground to 20 mesh $(<841 \mu \mathrm{m})$. Carbon and $\mathrm{N}$ concentrations of 298 woody samples were determined by dry combustion analysis of a $150 \mathrm{mg}$ subsample using a Vario Max $\mathrm{C} / \mathrm{N}$ analyzer ("Aspar 185" method; Elementar, Inc., Mt. Laurel, NJ). A subsample of each analyzed sample was dried for $24 \mathrm{~h}$ at $65{ }^{\circ} \mathrm{C}$ to determine moisture concentration, after which $\mathrm{C}$ and $\mathrm{N}$ values were corrected to a dry matter basis. Sample results were then correlated to total tree $\mathrm{C}$ and $\mathrm{N}$ content on a percent dry-weight basis.

Dry weight, $\mathrm{C}$ and $\mathrm{N}$ stock, and $\log -\log$ models

The total above- and below-ground dry weight $\left(\mathrm{DW}_{\mathrm{w}}\right)$, carbon $\left(\mathrm{C}_{\mathrm{w}}\right)$, and nitrogen $\left(\mathrm{N}_{\mathrm{w}}\right)$ stock was calculated as the sum of each above- and belowground woody tree component $n$ : 
Table 2 Black walnut tree sample characteristics: average $( \pm$ SE) tree age and size, above- and belowground $\mathrm{DW}_{\mathrm{w}}, \mathrm{C}_{\mathrm{w}}$ and $\mathrm{N}_{\mathrm{w}}$, and tree compartment $\mathrm{C}$ and $\mathrm{N}$ from four alley cropping sites in Missouri and Arkansas, USA in 2011

$\mathrm{DW}_{\mathrm{w}}$, dry weight; $\mathrm{DBH}$, tree diameter $(\mathrm{cm})$ at $137 \mathrm{~cm}$ above soil level; $\mathrm{r}$, DW:FW ratio; RS, rootshoot ratio; $\mathrm{C}_{\mathrm{n}}$, carbon concentration; $\mathrm{C}_{\mathrm{w}}$, carbon stock; $\mathrm{N}_{\mathrm{n}}$, nitrogen concentration; $\mathrm{N}_{\mathrm{w}}$, nitrogen stock; NF, New Franklin MO; MV, Mt. Vernon MO; FV, Fayetteville AR; BN, Booneville AR

${ }^{\text {a}}$ Post-transplanting age; all trees were 2 years old from seed when planted

${ }^{\mathrm{b}}$ Means across rows with the same letters are not different according to the Tukey Test $(p<0.05)$

${ }^{\mathrm{c}}$ Large branches $\geq 12 \mathrm{~cm}$ diameter, small branches $<12 \mathrm{~cm}$ diameter ${ }^{\mathrm{d}}$ Large roots $\geq 1.6 \mathrm{~cm}$ diameter, small roots $<1.6 \mathrm{~cm}$ diameter

\begin{tabular}{|c|c|c|c|c|c|}
\hline Variable & Sub-variable & $\mathrm{NF}$ & MV & FV & $\mathrm{BN}$ \\
\hline \multirow[t]{3}{*}{$\begin{array}{l}\text { Tree } \\
\text { age/size }\end{array}$} & $\begin{array}{l}\text { Tree age } \\
\text { (year) }^{\mathrm{a}}\end{array}$ & 10.0 & 10.0 & 11.0 & 8.9 \\
\hline & Height (m) & $5.4 \pm 0.4$ & $5.2 \pm 0.2$ & $4.5 \pm 0.2$ & $7.0 \pm 0.4$ \\
\hline & $\mathrm{DBH}(\mathrm{cm})$ & $10.9 \pm 1.1$ & $9.5 \pm 0.6$ & $7.1 \pm 0.5$ & $15.0 \pm 1.0$ \\
\hline \multirow[t]{4}{*}{$\begin{array}{l}\text { Above } \\
\text { ground }\end{array}$} & $\begin{array}{l}\mathrm{DW}_{\mathrm{w}} \\
\quad\left(\mathrm{kg} \mathrm{tree}^{-1}\right)\end{array}$ & $36.8 \pm 8.3$ & $17.0 \pm 2.2$ & $10.2 \pm 1.2$ & $36.0 \pm 3.4$ \\
\hline & $\mathrm{r}$ & $0.61 \pm 0.01$ & $0.59 \pm 0.01$ & $0.58 \pm 0.01$ & $0.62 \pm 0.02$ \\
\hline & $\mathrm{C}_{\mathrm{w}}\left(\mathrm{kg}\right.$ tree $\left.^{-1}\right)$ & $17.0 \pm 3.8 \mathrm{a}^{\mathrm{b}}$ & $8.0 \pm 0.1 \mathrm{~b}$ & $4.8 \pm 0.5 \mathrm{~b}$ & $17.1 \pm 1.6 \mathrm{a}$ \\
\hline & $\mathrm{N}_{\mathrm{w}}\left(\mathrm{kg}\right.$ tree $\left.^{-1}\right)$ & $0.091 \pm 0.022 \mathrm{a}$ & $0.054 \pm 0.005 \mathrm{ab}$ & $0.023 \pm 0.003 \mathrm{~b}$ & $0.040 \pm 0.003 \mathrm{~b}$ \\
\hline \multirow[t]{4}{*}{$\begin{array}{l}\text { Below } \\
\text { ground }\end{array}$} & $\begin{array}{l}\mathrm{DW}_{\mathrm{w}} \\
\quad\left(\mathrm{kg} \text { tree }^{-1}\right)\end{array}$ & - & $9.6 \pm 1.1$ & - & $18.0 \pm 2.2$ \\
\hline & $\mathrm{r}$ & - & $0.44 \pm 0.01$ & - & $0.48 \pm 0.01$ \\
\hline & $\mathrm{C}_{\mathrm{w}}\left(\mathrm{kg}\right.$ tree $\left.^{-1}\right)$ & - & $4.4 \pm 0.5 \mathrm{a}$ & - & $8.2 \pm 1.1 \mathrm{a}$ \\
\hline & $\mathrm{N}_{\mathrm{w}}\left(\mathrm{kg}\right.$ tree $\left.^{-1}\right)$ & - & $0.095 \pm 0.011 \mathrm{~b}$ & - & $0.120 \pm 0.017 \mathrm{a}$ \\
\hline RS & $\left(\mathrm{kg} \mathrm{kg}^{-1}\right)$ & - & $0.575 \pm 0.02$ & - & $0.509 \pm 0.048$ \\
\hline \multicolumn{6}{|c|}{ Trunk $C_{n}$ and $N_{n}$} \\
\hline \multirow[t]{2}{*}{ at $30 \mathrm{~cm}$} & $\mathrm{C}\left(\mathrm{g} \mathrm{kg}^{-1}\right)$ & $461.0 \pm 1.6$ & $472.0 \pm 0.7$ & $469.4 \pm 0.7$ & $472.4 \pm 1.1$ \\
\hline & $\mathrm{N}\left(\mathrm{g} \mathrm{kg}^{-1}\right)$ & $1.9 \pm 0.2$ & $1.7 \pm 0.2$ & $1.2 \pm 0$ & $1.1 \pm 0.1$ \\
\hline \multirow[t]{2}{*}{ at $60 \mathrm{~cm}$} & $\mathrm{C}\left(\mathrm{g} \mathrm{kg}^{-1}\right)$ & $459.2 \pm 6.5$ & $471.8 \pm 1.4$ & $469.2 \pm 0.7$ & $476.2 \pm 1.1$ \\
\hline & $\mathrm{N}\left(\mathrm{g} \mathrm{kg}^{-1}\right)$ & $1.8 \pm 0.1$ & $1.8 \pm 0.2$ & $1.4 \pm 0.1$ & $1.2 \pm 0.1$ \\
\hline \multirow[t]{2}{*}{ at $120 \mathrm{~cm}$} & $\mathrm{C}\left(\mathrm{g} \mathrm{kg}^{-1}\right)$ & $465.8 \pm 1.6$ & $471.8 \pm 1$ & $468.0 \pm 0.7$ & $476.0 \pm 1.0$ \\
\hline & $\mathrm{N}\left(\mathrm{g} \mathrm{kg}^{-1}\right)$ & $1.7 \pm 0.2$ & $2.4 \pm 0.2$ & $1.6 \pm 0.1$ & $1.1 \pm 0.1$ \\
\hline \multirow[t]{2}{*}{ at $180 \mathrm{~cm}$} & $\mathrm{C}\left(\mathrm{g} \mathrm{kg}^{-1}\right)$ & $466.4 \pm 2.5$ & $466.4 \pm 2.7$ & $466.5 \pm 0.9$ & $476.4 \pm 0.9$ \\
\hline & $\mathrm{N}\left(\mathrm{g} \mathrm{kg}^{-1}\right)$ & $1.6 \pm 0.2$ & $2.6 \pm 0.1$ & $1.8 \pm 0.2$ & $1.0 \pm 0.1$ \\
\hline \multicolumn{6}{|c|}{ Branch $\mathrm{C}_{\mathrm{n}}$ and $\mathrm{N}_{\mathrm{n}}^{\mathrm{c}}$} \\
\hline \multirow[t]{2}{*}{ Large } & $\mathrm{C}\left(\mathrm{g} \mathrm{kg}^{-1}\right)$ & - & $475.3 \pm 0.9$ & $472.1 \pm 1.2$ & $477.5 \pm 0.5$ \\
\hline & $\mathrm{N}\left(\mathrm{g} \mathrm{kg}^{-1}\right)$ & - & $2.4 \pm 0.1$ & $2.2 \pm 0.1$ & $1.4 \pm 0.1$ \\
\hline \multirow[t]{2}{*}{ Small } & $\mathrm{C}\left(\mathrm{g} \mathrm{kg}^{-1}\right)$ & $461.7 \pm 1.2$ & $472.7 \pm 0.9$ & $473.9 \pm 1.3$ & - \\
\hline & $\mathrm{N}\left(\mathrm{g} \mathrm{kg}^{-1}\right)$ & $4.3 \pm 0.6$ & $8.4 \pm 0.3$ & $5.4 \pm 0.2$ & - \\
\hline \multicolumn{6}{|c|}{ Root $C_{n}$ and $N_{n}^{d}$} \\
\hline \multirow[t]{2}{*}{ Large } & $\mathrm{C}\left(\mathrm{g} \mathrm{kg}^{-1}\right)$ & - & $468.9 \pm 1.1$ & - & $460.9 \pm 2.3$ \\
\hline & $\mathrm{N}\left(\mathrm{g} \mathrm{kg}^{-1}\right)$ & - & $9.0 \pm 0.8$ & - & $3.9 \pm 0.5$ \\
\hline \multirow[t]{2}{*}{ Small } & $\mathrm{C}\left(\mathrm{g} \mathrm{kg}^{-1}\right)$ & - & $441.3 \pm 3.8$ & - & $442.5 \pm 2.3$ \\
\hline & $\mathrm{N}\left(\mathrm{g} \mathrm{kg}^{-1}\right)$ & - & $16.7 \pm 1$ & - & $9.6 \pm 0.6$ \\
\hline \multirow[t]{2}{*}{ Root bole } & $\mathrm{C}\left(\mathrm{g} \mathrm{kg}^{-1}\right)$ & - & $453.5 \pm 8.7$ & - & - \\
\hline & $\mathrm{N}\left(\mathrm{g} \mathrm{kg}^{-1}\right)$ & - & $2.7 \pm 0.2$ & - & - \\
\hline
\end{tabular}




$$
\begin{aligned}
& D W_{w}=\sum_{i=1}^{n} \bar{r}_{n} * F W_{n} \\
& C_{w}=\sum_{i=1}^{n} \bar{r}_{n} * F W_{n} * \overline{C_{n}} \\
& N_{w}=\sum_{i=1}^{n} \bar{r}_{n} * F W_{n} * \overline{N_{n}}
\end{aligned}
$$

where $\mathrm{DW}_{\mathrm{w}}=$ total above- or below-ground dry weight $(\mathrm{kg}) ; \mathrm{r}_{\mathrm{n}}=$ average $\mathrm{DW}: \mathrm{FW}$ ratio of sample DW divided by sample FW of tree component $n$ (i.e., trunk, branches, roots) $\left(\mathrm{kg} \mathrm{kg}^{-1}\right) ; \mathrm{FW}_{\mathrm{n}}=$ measured tree component fresh weight $(\mathrm{kg}) ; \mathrm{C}_{\mathrm{w}}=$ total aboveor below-ground carbon stock $(\mathrm{kg}) ; \mathrm{C}_{\mathrm{n}}=$ average sample carbon concentration of tree component $n\left(\mathrm{~g} \mathrm{~kg}^{-1}\right) ; \mathrm{N}_{\mathrm{w}}=$ total above- or below-ground nitrogen stock $(\mathrm{kg}) ; \mathrm{N}_{\mathrm{n}}=$ average sample nitrogen concentration of tree component $n\left(\mathrm{~g} \mathrm{~kg}^{-1}\right)$.

The sample tree root-shoot ratio (RS) was calculated as the quotient of below- and above-ground $\mathrm{DW}_{\mathrm{w}}$. An allometric equation (log-log model) with $\mathrm{DBH}$ as independent variable, and $\mathrm{DW}_{\mathrm{w}}, \mathrm{C}_{\mathrm{w}}$, and $\mathrm{N}_{\mathrm{w}}$ as dependent variables was developed:

$\ln (y)=\ln (a)+b * \ln (x)$

where $\mathrm{y}$ is the response variable (above- and belowground $\mathrm{DW}_{\mathrm{w}}, \mathrm{C}_{\mathrm{w}}$, and $\mathrm{N}_{\mathrm{w}}$, all in $\mathrm{kg}$ ), a is the intercept, $\mathrm{X}$ is the explanatory variable $\mathrm{DBH}(\mathrm{cm})$, and $\mathrm{b}$ is the slope.

Equation (4) was used to calculate total $\mathrm{DW}_{\mathrm{w}}, \mathrm{C}_{\mathrm{w}}$, and $\mathrm{N}_{\mathrm{w}}$ for the $\mathrm{FV}$ site using $\mathrm{DBH}$ measurements for the ten excavated trees plus 38 additional similar-ageand-size black walnut trees at the site that were not excavated (Sauer et al., 2015). To minimize the bias introduced by logarithmic transformation, a correction factor proposed by Shen and Zhu (2008) was used as a multiplier, which yielded reliable estimates and predictions (Clifford et al. 2013). The correction factor was calculated with a, b, and the model estimate of $\sigma$, and ranged from 1.004 to 1.028 .

C accumulation $\left(d \mathrm{C}_{\mathrm{w}}\right)$, and $\mathrm{N}$ uptake rates $\left(d \mathrm{C}_{\mathrm{w}}\right)$ for the $\mathrm{FV}$ site were calculated on the tree stand and average tree as $\mathrm{C}_{\mathrm{w}}$ divided by years after planting (i.e., 11 years). The same calculation was used for $\mathrm{N}_{\mathrm{w}}$ uptake and $\mathrm{DW}_{\mathrm{w}}$ growth.
Statistical analyses

Differences among above- and below-ground tree tissue, and site for $\mathrm{C}_{\mathrm{w}}$ and $\mathrm{N}_{\mathrm{w}}$ were statistically analyzed with two-way analysis of variance (ANOVA) with site and tissue as factors $(p \leq 0.05)$, using the aov-and anova-function in R (R Foundation for Statistical Computing, Vienna, Austria). Differences among means were statistically analyzed with Tukey Test, using the TukeyHSD-function in R. An analysis of covariance (ANCOVA) with site as covariate was used in Eq. (4) to determine if the slope and intercepts were significantly different among sites ( $p \leq 0.05$ ). A step by step approach was used to find the most parsimonious model (i.e., from differences in slopes and/or intercepts to no differences among sites). The log-log models and ANCOVA were calculated in $\mathrm{R}$ using the $l m$-, step-, and anova-function. Differences in SOC and TN among sites, soil depth, and distance to the tree were statistically analyzed with three-way ANOVA and Tukey Test in R.

\section{Results}

Tree $\mathrm{C}_{\mathrm{w}}$ and $\mathrm{N}_{\mathrm{w}}$ across sites

Mean tree height and DBH varied among sites, ranging from $4.5-7.0 \mathrm{~m}$ and $7.1-15.0 \mathrm{~cm}$, respectively, and increased in the order $\mathrm{FV}<\mathrm{MV}<\mathrm{NF}<$ BN (Table 2). Similarly, the above- and belowground $\mathrm{DW}_{\mathrm{w}}$ varied among sites, with average aboveground $\mathrm{DW}_{\mathrm{w}}$ ranging from $10.2 \mathrm{~kg}^{-1}$ tree ${ }^{-1} \mathrm{FV}$ to $36.0 \mathrm{~kg}$ tree $^{-1}$ at $\mathrm{NF}$, and below-ground $\mathrm{DW}_{\mathrm{w}}$ $9.6 \mathrm{~kg}$ tree ${ }^{-1}$ at $\mathrm{MV}$ and $18.0 \mathrm{~kg}$ tree ${ }^{-1}$ at BN. Total tree $\mathrm{DW}_{\mathrm{w}}$ for these $\approx 10$-year-old trees ranged from $26.6 \mathrm{~kg}^{-1}$ at $\mathrm{MV}$ to $54.0 \mathrm{~kg}$ tree ${ }^{-1}$ at $\mathrm{BN}$. The DW:FW ratio (r) was higher for above-ground tissues compared with below-ground tissues. The root-shoot ratio (RS) was 0.575 and $0.509 \mathrm{~kg} \mathrm{~kg}^{-1}$ at the $\mathrm{MV}$ and BN site, respectively. While the soil site index (Table 1; Carmean et al. 1989) was least favorable at $\mathrm{BN}$, other factors such as higher annual rainfall, warmer weather, and a longer growing season at that more southerly site may have influenced tree growth there.

Differences in $C_{n}$ and $N_{n}$ concentrations in trees were noted among the four sites and among tissues (Table 2). Interestingly, while woody tissues at BN 
Table 3 Log- $\log$ model coefficients for $\mathrm{DW}_{\mathrm{w}}, \mathrm{C}_{\mathrm{w}}$ (both $\mathrm{kg}$ ), and $\mathrm{N}_{\mathrm{w}}(\mathrm{g}$ ), with mean intercept a, mean slope $\mathrm{b}$, and coefficient of determination $\mathrm{R}^{2}$

\begin{tabular}{|c|c|c|c|c|c|c|}
\hline $\begin{array}{l}\text { Above- } \\
\text { ground }\end{array}$ & Variables & Parameters & NF & MV & FV & $\mathrm{BN}$ \\
\hline & $\mathrm{DW}_{\mathrm{w}}$ & $\mathrm{a}$ & $-0.500 *$ & \multicolumn{3}{|c|}{$-0.948 * * *$} \\
\hline & & $\mathrm{b}$ & \multicolumn{4}{|c|}{$1.663 * * *$} \\
\hline & & $\mathrm{R}^{2}$ & \multicolumn{4}{|c|}{0.90} \\
\hline & $\mathrm{C}_{\mathrm{w}}$ & $\mathrm{a}$ & $-1.286^{* * *}$ & \multicolumn{3}{|c|}{$-1.711 * * *$} \\
\hline & & $\mathrm{b}$ & \multicolumn{4}{|c|}{$1.670 * * *$} \\
\hline & & $\mathrm{R}^{2}$ & \multicolumn{4}{|c|}{0.90} \\
\hline & $\mathrm{N}_{\mathrm{w}}$ & $\mathrm{a}$ & 0.65 & & $0.168 * * *$ & $-0.375 * * *$ \\
\hline & & $\mathrm{b}$ & \multicolumn{4}{|c|}{$1.505 * * *$} \\
\hline & & $\mathrm{R}^{2}$ & \multicolumn{4}{|c|}{0.78} \\
\hline $\begin{array}{l}\text { Below- } \\
\text { ground }\end{array}$ & Variables & Parameters & \multicolumn{2}{|c|}{ MV } & \multicolumn{2}{|c|}{$\mathrm{BN}$} \\
\hline & $\mathrm{DW}_{\mathrm{w}}$ & $\mathrm{a}$ & \multicolumn{4}{|c|}{$-0.861 \mathrm{~ns}$} \\
\hline & & $\mathrm{b}$ & \multicolumn{4}{|c|}{$1.371 * * *$} \\
\hline & & $\overline{\mathrm{R}^{2}}$ & \multicolumn{4}{|c|}{0.75} \\
\hline & $\mathrm{C}_{\mathrm{w}}$ & $\mathrm{a}$ & \multicolumn{4}{|c|}{$-1.656^{* *}$} \\
\hline & & $\mathrm{b}$ & \multicolumn{4}{|c|}{$1.372 * * *$} \\
\hline & & $\mathrm{R}^{2}$ & \multicolumn{4}{|c|}{0.75} \\
\hline & $\mathrm{N}_{\mathrm{w}}$ & $\mathrm{a}$ & \multicolumn{4}{|c|}{$2.551 * * *$} \\
\hline & & $\mathrm{b}$ & \multicolumn{4}{|c|}{$0.836^{* * *}$} \\
\hline & & $\mathrm{R}^{2}$ & \multicolumn{4}{|c|}{0.44} \\
\hline
\end{tabular}

Note that these models were developed with a DBH range of $4.5-18.3 \mathrm{~cm}$, and that predicted values outside that range may not be correct

$\mathrm{DW}_{\mathrm{w}}$, dry weight; $\mathrm{C}_{\mathrm{w}}$, carbon stock; $\mathrm{N}_{\mathrm{w}}$, nitrogen stock; DBH, tree diameter $(\mathrm{cm})$ at $137 \mathrm{~cm}$ above soil level; NF, New Franklin MO; MV, Mt. Vernon MO; FV, Fayetteville AR; BN, Booneville AR

$* p<0.05 ; * * p<0.01 ; * * * p<0.001 ; \mathrm{ns}=$ not significant

generally had higher $\mathrm{C}_{\mathrm{n}}$, they had the lowest $\mathrm{N}_{\mathrm{n}}$, with tissues at NF being the opposite (lowest $\mathrm{C}_{n}$ but among the highest $\mathrm{N}_{\mathrm{n}}$ ). One possible hypothesis for the lower level of $\mathrm{N}$ at $\mathrm{BN}$ is that those trees were already producing heavy nut crops; the nuts might have been aggressive sinks for mobile $\mathrm{N}$ in the trees. Above ground tissues (both trunks and large branches) tended to have higher $C_{n}$ but lower $N_{n}$ compared with belowground tissues. The total above- and below-ground $\mathrm{C}_{\mathrm{w}}$ ranged from $4.8-17.1$ and $4.4-8.2 \mathrm{~kg} \mathrm{C}$ tree $^{-1}$, respectively. The total above- and below-ground $\mathrm{N}_{\mathrm{w}}$ ranged from 0.023-0.091 and $0.095-0.120 \mathrm{~kg} \mathrm{~N}$ tree ${ }^{-1}$, respectively. Above- ground $\mathrm{C}_{\mathrm{w}}$ was significantly higher at $\mathrm{NF}$ and $\mathrm{BN}$ than at $\mathrm{MV}$ and $\mathrm{FV}$, while $\mathrm{N}_{\mathrm{w}}$ was higher at $\mathrm{NF}$ than at $\mathrm{FV}$ and $\mathrm{BN}$. Mean $\mathrm{C}_{\mathrm{w}}$ across all sites was significantly higher in above-ground tissues $\left(11.7 \mathrm{~kg}^{-1} \mathrm{tree}^{-1}\right)$ compared with below-ground $\left(6.3 \mathrm{~kg}\right.$ tree $\left.{ }^{-1}\right)$, while $\mathrm{N}_{\mathrm{w}}$ was higher in below-ground tissues $\left(0.108 \mathrm{~kg}\right.$ tree $\left.^{-1}\right)$ compared with above-ground $\left(0.052 \mathrm{~kg} \mathrm{tree}^{-1}\right)$. Site $\times$ tree tissue interactions for $\mathrm{C}_{\mathrm{w}}$ and $\mathrm{N}_{\mathrm{w}}$ in this study were not statistically significant $(p<0.05)$.

The above-ground $\mathrm{DW}_{\mathrm{w}}, \mathrm{C}_{\mathrm{w}}$, and $\mathrm{N}_{\mathrm{w}} \log -\log$ models were significantly different in intercepts among sites, but slopes were not different (Table 3; Figs. 1, 2). The above-ground log-log models 

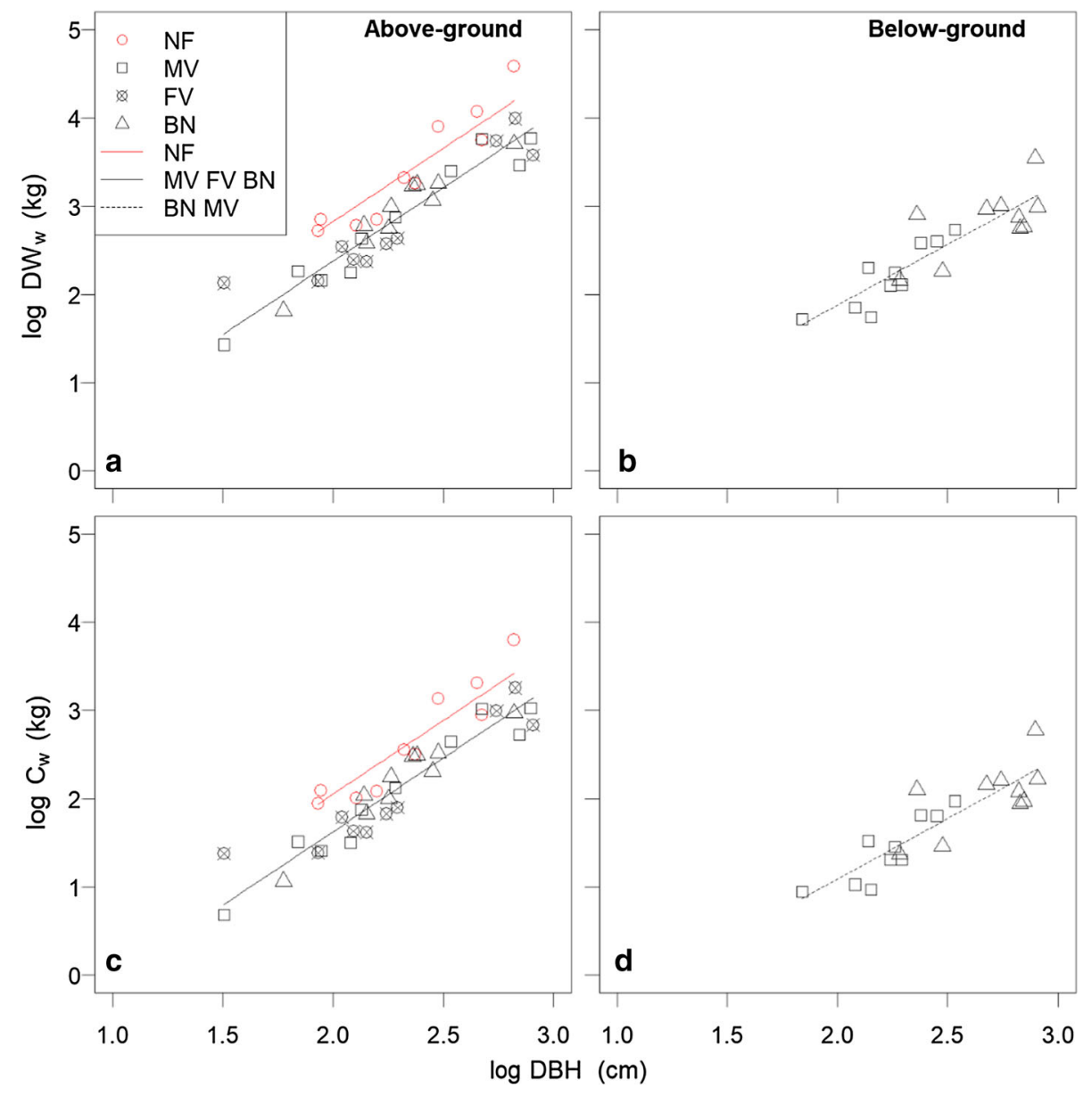

Fig. 1 Site-specific log-log models with above-ground (a, c) and below-ground $(\mathbf{b}, \mathbf{d})$ dry weight $\left(\mathrm{DW}_{\mathrm{w}}\right)(\mathbf{a}, \mathbf{b})$ and carbon respectively. All sites have the same slope, but intercepts differ $\left(\mathrm{C}_{\mathrm{w}}\right)(\mathbf{c}, \mathbf{d})$ as dependent, and $\mathrm{DBH}$ as independent variable, in above-ground $\mathrm{DW}_{\mathrm{w}}$ and $\mathrm{C}_{\mathrm{w}}$ on the $\mathrm{NF}$ site. $\mathrm{DBH}=$ tree diameter $(\mathrm{cm})$ at $137 \mathrm{~cm}$ above soil level

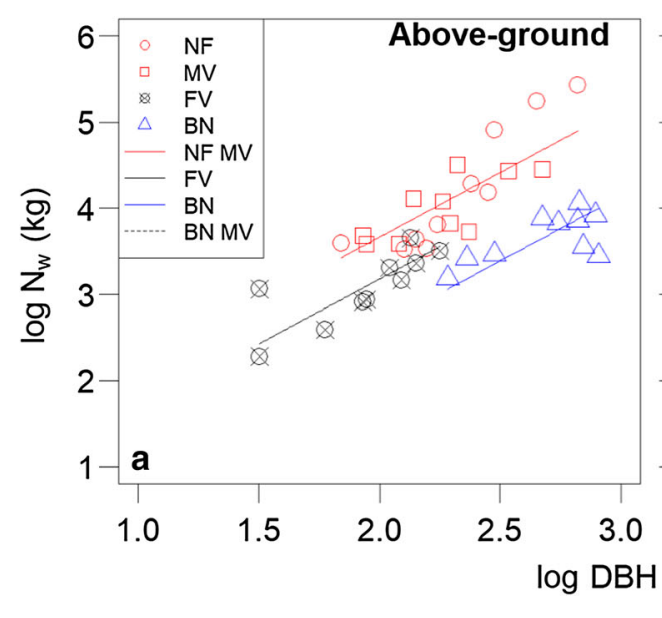

Fig. 2 Site-specific $\log -\log$ models with above-ground (a) and below-ground (b) nitrogen $\left(\mathrm{N}_{\mathrm{w}}\right)$ as dependent, and DBH as independent variable, respectively. All sites have the same

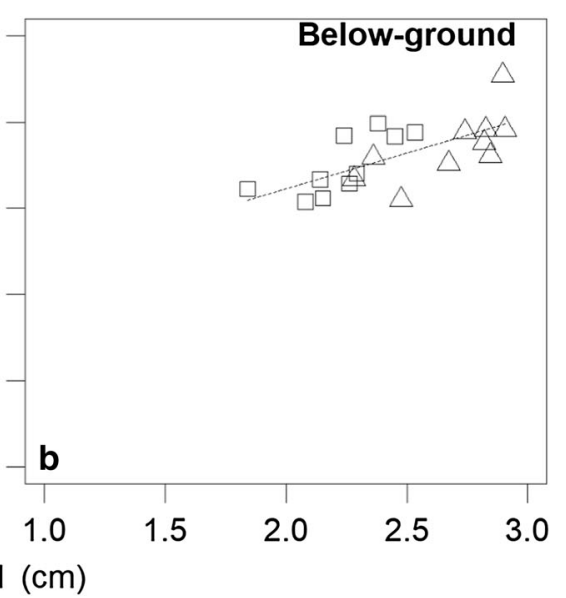

slope, but intercepts differ in above-ground $\mathrm{N}_{\mathrm{w}}$ among sites. $\mathrm{DBH}=$ tree diameter $(\mathrm{cm})$ at $137 \mathrm{~cm}$ above soil level 
Table 4 Statistical analysis $^{\mathrm{a}}$ of soil organic carbon (SOC) and total $\mathrm{N}$ (TN) concentrations in soil core samples from four black walnut alley cropping sites in Missouri and Arkansas, USA, at three distances and four depths adjacent to the trees in Spring 2011

NF, New Franklin MO;

MV, Mt. Vernon MO; FV, Fayetteville AR; BN, Booneville AR

${ }^{\mathrm{a}}$ Means within sub-columns with the same letters are not different according to the Tukey Test $(p<0.05)$; $* * * p<0.001 ; n s$ not significant

${ }^{\mathrm{b}}$ Without BN and FV site, low sample size

\begin{tabular}{|c|c|c|c|}
\hline Variable & Sub-variable & $\mathrm{SOC}\left(\mathrm{g} \mathrm{kg}^{-1}\right)$ & $\mathrm{TN}\left(\mathrm{g} \mathrm{kg}^{-1}\right)$ \\
\hline \multirow[t]{5}{*}{ Site } & NF & $8.1 \pm 0.3 \mathrm{~d}$ & $1.14 \pm 0.03 b$ \\
\hline & MV & $9.2 \pm 0.4 \mathrm{c}$ & $1.17 \pm 0.03 b$ \\
\hline & $\mathrm{FV}$ & $12.6 \pm 0.6 \mathrm{a}$ & $1.21 \pm 0.05 \mathrm{ab}$ \\
\hline & $\mathrm{BN}$ & $10.3 \pm 0.5 b$ & $1.27 \pm 0.04 \mathrm{a}$ \\
\hline & $p$ & $* * *$ & $* * *$ \\
\hline \multirow[t]{4}{*}{ Distance (m) } & 1 & $9.5 \pm 0.4$ & $1.17 \pm 0.03$ \\
\hline & 2 & $9.6 \pm 0.4$ & $1.19 \pm 0.03$ \\
\hline & 3 & $10 \pm 0.4$ & $1.21 \pm 0.03$ \\
\hline & $p$ & ns & ns \\
\hline \multirow[t]{5}{*}{ Depth $(\mathrm{cm})$} & $0-10$ & $16.3 \pm 0.4 \mathrm{a}$ & $1.71 \pm 0.03 \mathrm{a}$ \\
\hline & $10-20$ & $9 \pm 0.2 b$ & $1.14 \pm 0.02 b$ \\
\hline & $20-50$ & $5.7 \pm 0.1 \mathrm{c}$ & $0.87 \pm 0.02 \mathrm{c}$ \\
\hline & $50-100^{\mathrm{b}}$ & $4.1 \pm 0.1 \mathrm{c}$ & $0.77 \pm 0.02 \mathrm{c}$ \\
\hline & $p$ & $* * *$ & $* * *$ \\
\hline Site $\times$ distance & $p$ & ns & ns \\
\hline Site $\times$ depth & $p$ & $* * *$ & $* * *$ \\
\hline Distance $\times$ depth & $p$ & ns & ns \\
\hline Site $\times$ dist $\times$ depth & $p$ & ns & ns \\
\hline
\end{tabular}

explained 78-90\% of the variation. The site-specific $\mathrm{DW}_{\mathrm{w}}$ and $\mathrm{C}_{\mathrm{w}}$ intercepts were significantly higher at $\mathrm{NF}$ than at $\mathrm{BN}, \mathrm{MV}$, and $\mathrm{FV}$. The $\mathrm{N}_{\mathrm{w}}$ intercept was different and increased in the order $\mathrm{BN}<\mathrm{FV}<\mathrm{NF}=$ MV. The slope and intercept of the below-ground $\mathrm{DW}_{\mathrm{w}}, \mathrm{C}_{\mathrm{w}}$, and $\mathrm{N}_{\mathrm{w}} \log -\log$ models at $\mathrm{BN}$ and $\mathrm{MV}$ were not different, and explained $44-75 \%$ of the variation.

The total black walnut stand and individual tree average $\mathrm{DW}_{\mathrm{w}}, \mathrm{C}_{\mathrm{w}}$, and $\mathrm{N}_{\mathrm{w}}$ were calculated for the FV site (1.25 ha) using the site-specific log-log model equation (Eq. 4; Table 3). Total above-ground tree stand $\mathrm{DW}_{\mathrm{w}}$ was $691 \mathrm{~kg} \mathrm{ha}^{-1}$ with an average of $18.0 \mathrm{~kg}$ tree ${ }^{-1}$. Total $\mathrm{C}_{\mathrm{w}}$ was $327 \mathrm{~kg} \mathrm{ha}^{-1}$ with an average $\mathrm{C}_{\mathrm{w}}$ of $8.5 \mathrm{~kg}$ tree ${ }^{-1}$. Carbon accumulation rate was $29.7 \mathrm{~kg} \mathrm{ha}^{-1}$ year $^{-1}$. Total $\mathrm{N}_{\mathrm{w}}$ was $1.46 \mathrm{~kg} \mathrm{ha}^{-1}$ and on average $38.1 \mathrm{~g} \mathrm{tree}^{-1}$. The $\mathrm{N}_{\mathrm{w}}$ uptake rate was $133.1 \mathrm{~g} \mathrm{ha}^{-1}$ year $^{-1}$.

\section{SOC and soil TN}

Significant differences in background SOC and soil TN were noted among the four sites (Table 4). The SOC and TN did not differ with increasing distances from the tree trunks collectively or across strata at the various soil depths, and there were no significant site $\times$ distance interactions. The highest SOC and TN were consistently found in the top $10 \mathrm{~cm}$ of soil, with consistent and significant decreases in SOC and TN with increasing depth. We also found consistent site $\times$ depth interactions.

\section{Discussion}

Above- and below-ground biomass $\mathrm{C}$ and $\mathrm{N}$

Despite similar tree age, differences in mean tree heights and DBH as well as in $\mathrm{DW}_{\mathrm{w}}, \mathrm{C}_{\mathrm{w}}$ and $\mathrm{N}_{\mathrm{w}}$ were detected among sites, likely due to varying site, climatic, and management factors. The fragipan soil at FV was the least suitable for black walnut trees and was manifested in poor tree growth overall. This may have limited the uptake of soil $\mathrm{N}$ through reduced root exploration of the soil profile. Zhang et al. (2017) noted increasing RS with increasing age for plantation-grown Juglans regia, but their RS at similar tree age (0.27-0.30) was lower compared with this study. Our above-ground $C_{n}$ concentrations were within the range of temperate angiosperm tree species (Thomas and Martin 2012), higher than reported by Zhang et al. (2017) for J. regia (421.6-464.6 $\mathrm{g} \mathrm{kg}^{-1}$ ) and by Cardinael et al. (2017) for hybrid walnut (J. regia $\times J$. nigra) (445.7 and $428.6 \mathrm{~g} \mathrm{~kg}^{-1}$ ), yet lower than reported by Lamlom and Savidge (2003) for J. nigra 
(491.7 $\mathrm{g} \mathrm{kg}^{-1}$ ). The below-ground $\mathrm{C}_{\mathrm{n}}$ was within the range of $J$. regia reported by Zhang et al. (2017). $\mathrm{N}_{\mathrm{n}}$ was higher than typical $\mathrm{N}$ ranges of wood tissue of $0.7-1.2 \mathrm{~g} \mathrm{~kg}^{-1}$ (Chave et al. 2009), especially the below-ground tissue. The wide range of $\mathrm{RS}$ and $\mathrm{C}_{\mathrm{n}}$ within Juglans $s p$. and the significant differences of $\mathrm{C}_{\mathrm{w}}$ and $\mathrm{N}_{\mathrm{w}}$ among sites and tissues indicate that more data are needed to accurately quantify the $\mathrm{C}$ and $\mathrm{N}$ accumulation in above- and below-ground tree compartments.

\section{Log-log models}

The log-log model intercept differed among sites, i.e., $\mathrm{DW}_{\mathrm{w}}, \mathrm{C}_{\mathrm{w}}$, and $\mathrm{N}_{\mathrm{w}}$ at $\mathrm{NF}$ and $\mathrm{MV}$ were higher at a given $\mathrm{DBH}$ than at $\mathrm{FV}$ and $\mathrm{BN}$. The above-ground intercepts increased along site latitudes, despite the growth-stunting conditions at the FV site (Tables 1, 3 ). This could indicate that above-ground intercepts were primarily influenced by environment. The slopes were not significantly different among sites, i.e., the $\mathrm{DW}_{\mathrm{w}}, \mathrm{C}_{\mathrm{w}}$, and $\mathrm{N}_{\mathrm{w}}$ increased per unit of $\mathrm{DBH}$ at the same rate. Site-specific differences were not detected for below-ground models, i.e., amount and rate of root $\mathrm{DW}_{\mathrm{w}}, \mathrm{C}_{\mathrm{w}}$, and $\mathrm{N}_{\mathrm{w}}$ in relation to $\mathrm{DBH}$ were equal among sites. To the best of our knowledge, there are no allometric equations previously published for J. nigra $\mathrm{DW}_{\mathrm{w}}, \mathrm{C}_{\mathrm{w}}$, or $\mathrm{NW}_{\mathrm{w}}$. Previous studies focused on nut production or wood volume allometry (Ares and Brauer 2004; Brauer et al. 2006), of which the latter can be used for $\mathrm{DW}_{\mathrm{w}}$ calculation. A generalized $\mathrm{DW}_{\mathrm{w}}$ model with $\mathrm{a}=-2.5095$ and $\mathrm{b}=2.5437$ was proposed for trees of the Juglandaceae family (Chojnacky et al. 2014), and previous open-grown J. nigra models focused on DBH growth over time or other allometrics (Cabanettes et al. 1998; McPherson et al., 2016). The study by Cardinael et al. (2017) was limited by using a generalized model for belowground biomass estimations and non-destructive measurements of J. nigra. The black walnut log-log models herein can predict $\mathrm{DW}_{\mathrm{w}}, \mathrm{C}_{\mathrm{w}}$, and $\mathrm{N}_{\mathrm{w}}$ for a wide DBH range $(4.5-18.3 \mathrm{~cm})$, with site-specific intercept adjustment (Table 3 ). We suggest selecting the coefficients with the most comparable conditions for use in other applications. Also, note that $\mathrm{R}^{2}$ values of the $\mathrm{N}_{\mathrm{w}}$ $\log -\log$ models were low, and we suggest using mean $\mathrm{N}_{\mathrm{n}}$ concentration and $\mathrm{DW}_{\mathrm{w}}$ coefficients to calculate total $\mathrm{N}$ uptake.
SOC and soil TN concentrations across sites

The significant differences in SOC and TN among sites were likely due to inherent local environmental and pedological conditions and characteristics, as management factors among sites were relatively similar. The highest SOC and TN in the upper soil layer is a consistent pattern commonly observed in a variety of soils and settings (e.g., Burner et al. 2013; Jobbagyi and Jackson 2000). The SOC and TN did not differ with distance from the trees which likely had not been established long enough (i.e., $\approx 10$ years) to spatially affect SOC concentrations. While tree roots should have been present in most of this soil profile (0-100 cm deep and 1-3 m laterally from trunk; except at FV due to fragipan), we were not able to attribute any of these SOC and TN differences to the presence of tree roots. Furthermore, control of perennial grasses and weeds within the drip line might have impacted tree root growth and SOC accumulation due to lack of cover and associated roots in those areas (Brauer et al. 2004; Burner et al. 2015; Mulia and Dupraz 2006). Cardinael et al. (2017) found high variation in SOC topsoil stocks in a 6-year-old hybrid walnut $(J$. regia $\times$ J. nigra) agroforestry system, with both significant increase and no change in SOC compared to monocropping, while older agroforestry systems showed consistent significant increases. Cardinael et al. (2018b) underscore the complexity of SOC and TN dynamics in agroforestry systems, of which tree roots are only one of numerous interacting and competing factors, both biological and physical.

Acknowledgments We thank the anonymous reviewers for their valuable input on this paper, and Karen Chapman, Larry Huddleston, Dan England, Ryan Lock, James Houx, Valen Tanner, Ben Poirot, Kevin Jensen, Amy Morrow, and David Den Haan for their technical expertise.

Funding This research was supported in part by the United States Department of Agriculture (USDA)-Agricultural Research Service (ARS), Dale Bumpers Small Farms Research Center, Booneville, Arkansas through Project 6227-21660-003-00D, and through a specific cooperative agreement (58-6227-1-004) between USDA-ARS and University of Missouri Center for Agroforestry. It was also supported by an appointment to the Agricultural Research Service (ARS) Research Participation Program administered by the Oak Ridge Institute for Science and Education (ORISE) through an interagency agreement between the U.S. Department of Energy (DOE) and USDA. ORISE is managed by Oak Ridge Associated Universities (ORAU) under DOE contract number 
DE-AC05-06OR23100. All opinions expressed in this paper are the authors' and do not necessarily reflect the policies and views of University of Missouri, USDA, ARS, DOE, or ORAU/ ORISE. USDA is an equal opportunity provider and employer. Mention of trade names or commercial products in this article is solely for the purpose of providing specific information and does not imply recommendation or endorsement by the USDA.

\section{Compliance with ethical standards}

Conflict of interest The authors declare that they have no conflict of interest associated with this research or publication.

Open Access This article is licensed under a Creative Commons Attribution 4.0 International License, which permits use, sharing, adaptation, distribution and reproduction in any medium or format, as long as you give appropriate credit to the original author(s) and the source, provide a link to the Creative Commons licence, and indicate if changes were made. The images or other third party material in this article are included in the article's Creative Commons licence, unless indicated otherwise in a credit line to the material. If material is not included in the article's Creative Commons licence and your intended use is not permitted by statutory regulation or exceeds the permitted use, you will need to obtain permission directly from the copyright holder. To view a copy of this licence, visit http://creativecommons.org/licenses/by/4.0/.

\section{References}

Ares A, Brauer D (2004) Growth and nut production of black walnut in relation to site, genotype and stand management in south-central United States. Agrofor Syst 63:83-90

Awaz M, Stokes A, Mao Z et al (2018) Linking above- and below-ground phenology of hybrid walnut growing along a climatic gradient in temperate agroforestry systems. Plant Soil 424:103-122

Benjamin TJ, Hoover WL, Seifert JR, Gillespie AR (2000) Defining competition vectors in a temperate alley cropping system in the midwestern USA: 4. The economic return of ecological knowledge. Agrofor Syst 48:79-93

Brauer D, Jones J (2003) Results on the establishment of named varieties of eastern black walnut on an upland site in the Ouachita region of Arkansas. Ann Rep North Nut Grow Assoc 94:133-145

Brauer D, Horton T, Burner D (2004) Effects of under-story management and forage species on soil moisture in a pecan alley cropping practice. Ann Rep North Nut Grow Assoc 95:27-37

Brauer D, Ares A, Reid W, Thomas A, Slusher JP (2006) Nutyield variations and yield-diameter relationships in opencanopy black walnut trees in southern USA. Agrofor Syst 67:63-72

Burner DM, Pote DH, Mackown CT (2013) Short-term responses for an emulated loblolly pine silvopasture. Commun Soil Sci Plant Anal 44:1708-1721

Burner DM, Brauer DK, Pote DH, Snider JL (2015) Effect of understory management on phenological responses of eastern black walnut on an alluvial Arkansas soil. Agrofor Syst 89:135-147

Cabanettes A, Auclair D, Imam W (1998) Diameter and height growth curves for widely-spaced trees in European agroforestry. Agrofor Syst 43:169-181

Câmara CRS, Schlegel V (2016) A review on the potential human health benefits of the black walnut: a comparison with the English walnuts and other tree nuts. Int J Food Prop 19:2175-2189

Cardinael R, Chevallier T, Cambou A et al (2017) Increased soil organic carbon stocks under agroforestry: a survey of six different sites in France. Agr Ecosyst Environ 236:243-255

Cardinael R, Umulisa V, Toudert A, Olivier A, Bockel L, Bernoux M (2018a) Revisiting IPCC Tier 1 coefficients for soil organic and biomass carbon storage in agroforestry systems. Environ Res Lett 13:124020

Cardinael R, Guenet B, Chevallier T, Dupraz C, Cozzi T, Chenu C (2018b) High organic inputs explain shallow and deep SOC storage in a long-term agroforestry system-combining experimental and modeling approaches. Biogeosciences 15:297-317

Carmean WH, Hahn JT, Jacobs RD (1989) Site index curves for forest tree species in the Eastern United States. General technical report NC-128. USDA Forest Service. North Central Forest Experiment Station, St. Paul, MN

Chave J, Coomes D, Jansen S, Lewis SL, Swenson NG, Zanne AE (2009) Towards a worldwide wood economics spectrum. Ecol Lett 12:351-366

Chenoweth B (1995) Black walnut: the history, use, and unrealized potential of a unique American renewable natural resource. Sagamore Publishing, Urbana

Chojnacky DC, Heath LS, Jenkins JC (2014) Updated generalized biomass equations for North American tree species. Forestry 87:129-151

Clifford D, Cressie N, England JR, Roxburgh SH, Paul KI (2013) Correction factors for unbiased, efficient estimation and prediction of biomass from log-log allometric models. For Ecol Manage 310:375-381

Coggeshall MV, Thomas AL, Van Sambeek JW (2003) Scion and rootstock effect on the performance of grafted black walnut cultivars. Comb Proc Int Plant Propagators' Soc 53:555-557

Dold C, Thomas AL, Ashworth AJ, Philipp D, Brauer DK, Sauer TJ (2019) Carbon sequestration and nitrogen uptake in a temperate silvopasture system. Nutr Cycl Agroecosyst 1:14

Dollinger J, Jose S (2018) Agroforestry for soil health. Agrofor Syst 92:213-219

Dupraz C, Simorte V, Dauzat M, Bertoni G, Bernadac A, Masson P (1999) Growth and nitrogen status of young walnuts as affected by intercropped legumes in a Mediterranean climate. In: Dupraz C, Auclair D (eds) Agroforestry for sustainable land-use fundamental research and modelling with emphasis on temperate and mediterranean applications. Springer, Berlin

Garner BA, Cox JB, Vodrazka FM, Winfrey AL (1980) Soil survey of Logan County, Arkansas. USDA Soil Conservation Service, U.S. Govt Printing Office, Washington

Garrett HE, Harper LS (1998) The science and practice of black walnut agroforestry in Missouri, USA: a temperate zone 
assessment. In: Buck LE, Lassoie JP, Fernandes ECM (eds) Agroforestry in sustainable agricultural systems. CRC Press, Washington

Germon A, Cardinael R, Prieto I et al (2016) Unexpected phenology and lifespan of shallow and deep fine roots of walnut trees grown in a silvoarable Mediterranean agroforestry system. Plant Soil 401:409-426

Grams TE, Andersen CP (2007) Competition for resources in trees: physiological versus morphological plasticity. In: Esser K, Lüttge U, Beyschlag W, Murata J (eds) Progress in botany. Springer, Berlin

Grogger HE, Landtiser GR (1978) Soil survey of Howard County, Missouri. USDA Soil Conservation Service, U.S. Govt Printing Office, Washington

Harmon ME (2001) Carbon sequestration in forests: addressing the scale question. J For 99:24-29

Harper MD, Phillips WM, Haley GJ (1969) Soil survey of Washington County, Arkansas. USDA Soil Conservation Service, U.S. Govt Printing Office, Washington

Hughes HE (1982) Soil survey of Greene and Lawrence Counties, Missouri. USDA Soil Conservation Service, U.S. Govt Printing Office, Washington

Jacobs DF, Selig MF, Severeid LR (2009) Aboveground carbon biomass in plantation-grown American chestnut (Castanea dentata) in absence of blight. For Ecol Manage 258:288-294

Jenkins JC, Chojnacky DC, Heath LS, Birdsey RA (2004) Comprehensive database of diameter-based biomass regressions for North American tree species. General technical report NE-319. USDA Forest Service, Northeastern Research Station, Newtown Square, PA

Jobbagyi EG, Jackson RB (2000) The vertical distribution of soil organic carbon and its relation to climate and vegetation. Ecol Appl 10:423-436

Lamlom SH, Savidge RA (2003) A reassessment of carbon content in wood: variation within and between 41 North American species. Biomass Bioenerg 25:381-388

Lines ER, Zavala MA, Purves DW, Coomes DA (2012) Predictable changes in aboveground allometry of trees along gradients of temperature, aridity and competition. Glob Ecol Biogeogr 21:1017-1028

McPherson EG, van Doorn NS, Peper PJ (2016) Urban tree database and allometric equations. General technical report PSW-GTR-253. USDA Forest Service, Pacific Southwest Research Station, Albany, CA

Mulia R, Dupraz C (2006) Unusual fine root distributions of two deciduous tree species in southern France: what consequences for modelling of tree root dynamics? Plant Soil 281:71-85

Nair PKR, Kumar BM, Nair VD (2009) Agroforestry as a strategy for carbon sequestration. J Plant Nutr Soil Sci 172:10-23

Nepal P, Ince PJ, Skog KE, Chang SJ (2012) Projection of U.S. forest sector carbon sequestration under U.S. and global timber market and wood energy consumption scenarios. Biomass Bioenerg 45:251-264

Profft I, Mund M, Weber G-E, Weller E, Schulze E-D (2009) Forest management and carbon sequestration in wood products. Eur J For Res 128:399-413

Ravishankara AR, Daniel JS, Portmann RW (2009) Nitrous oxide $\left(\mathrm{N}_{2} \mathrm{O}\right)$ : the dominant ozone-depleting substance emitted in the 21st century. Science 326(5949):123-125. https://doi.org/10.1126/science.1176985

Reid W, Coggeshall M, Garrett HE, Van Sambeek J (2009) Growing black walnut for nut production. Agroforestry in Action Pub AF1011-2009. University of Missouri Center for Agroforestry, Columbia, MO

Sauer TJ, Coblentz WK, Thomas AL, Brye KR, Brauer DK, Skinner JV, Brahana JV, DeFauw SL, Hays PD, Moffitt DC, Robinson JL, James TA, Hickie KA (2015) Nutrient cycling in an agroforestry alley cropping system receiving poultry litter or nitrogen fertilizer. Nutr Cycl Agroecosyst 101:167-179

Schroth G, da Mota MDSS, de Assis Elias ME (2015) Growth and nutrient accumulation of Brazil nut trees (Bertholletia excelsa) in agroforestry at different fertilizer levels. J For Res 26:347-353

Shen H, Zhu Z (2008) Efficient mean estimation in log-normal linear models. J Stat Plan Inference 138:552-567

Stovall JP, Fox TR, Seiler JR (2013) Allometry varies among 6-year-old Pinus taeda (L.) clones in the Virginia Piedmont. For Sci 59:50-62

Thomas SC, Martin AR (2012) Carbon content of tree tissues: a synthesis. Forests 3:332-352

Thomas AL, Brauer DK, Sauer TJ, Coggeshall MV, Ellersieck ML (2008) Cultivar influences early rootstock and scion survival of grafted black walnut. J Am Pomol Soc 62:3-12

Udawatta R, Jose S (2012) Agroforestry strategies to sequester carbon in temperate North America. Agrofor Syst $86: 225-242$

UNFCCC (2006) Handbook. United Nations Framework Convention on Climate Change UNFCCC, Bonn

Verchot LV, Van Noordwijk M, Kandji S, Tomich T, Ong C, Albrecht A, Mackensen J, Bantilan C, Anupama KV, Palm C (2007) Climate change: linking adaptation and mitigation through agroforestry. Mitig Adapt Strat Glob Change 12(5):901-918

Wolz KJ, DeLucia EH (2019) Black walnut alley cropping is economically competitive with row crops in the Midwest USA. Ecol Appl 29(1):e01829

Wolz KJ, Branham BE, DeLucia EH (2018) Reduced nitrogen losses after conversion of row crop agriculture to alley cropping with mixed fruit and nut trees. Agric Ecosyst Environ 258:172-181

Woodbury PB, Smith JE, Heath LS (2007) Carbon sequestration in the U.S. forest sector from 1990 to 2010. For Ecol Manage 241:14-27

Zellers CE, Saunders MR, Morrissey RC, Shields JM, Bailey BG, Dyer J, Cook J (2012) Development of allometric leaf area models for intensively managed black walnut (Juglans nigra L.). Ann For Sci 69:907-913

Zhang W, Ahanbieke P, Wang BJ, Gan YW, Li LH, Christie P, Li L (2015) Temporal and spatial distribution of roots as affected by interspecific interactions in a young walnut/ wheat alley cropping system in northwest China. Agrofor Syst 89:327-343

Zhang H, Wang K, Zeng Z, Du H, Zeng F (2017) Biomass and carbon sequestration by Juglans regia plantations in the karst regions of Southwest China. Forests 8:103

Zhou X, Brandle JR, Awada TN, Schoeneberger MM, Martin DL, Xin Y, Tang Z (2011) The use of forest-derived specific gravity for the conversion of volume to biomass for 
open-grown trees on agricultural land. Biomass Bioenerg 35:1721-1731

Zhou X, Schoeneberger MM, Brandle JR et al (2014) Analyzing the uncertainties in use of forest-derived biomass equations for open-grown trees in agricultural land. For Sci 61:144-161
Publisher's Note Springer Nature remains neutral with regard to jurisdictional claims in published maps and institutional affiliations. 